\title{
УПОТРЕБА ОНЛАЈН ПЛАТФОРМЕ МУДЛ (MOODLE) У РЕФОРМИСАНОЈ НАСТАВИ КАТЕДРЕ ЗА НЕОХЕЛЕНСКЕ СТУ ДИЈЕ ФИЛОЛОШКОГ ФАКУЛТЕТА УНИВЕРЗИТЕТА У БЕОГРАДУ
}

АПСТРАКТ: У овом раду разматра се учење новогрчког језика употребом електронске платформе Мудл (Moodle) у склопу „хибридног” и онлајн учења. Посебна пажња биће посвећена анализи режима рада поменутог интерактивног онлајн система као одговора на захтеве савремене академске заједнице, уз његову имплементацију у наставу основних студија Катедре за неохеленске студије Филолошког факултета Универзитета у Београду. У вези са тим, биће наведени случајеви конкретне примене информационо-комуникационих технологија у креирању дигитализованих садржаја за потребе предмета Савремени грчки језик Г-1 и Грчка кюижевност 1. Истовремено, образложићемо чињеницу трансформације електронских материјала од иницијално комплементарних средстава учења до обавезне допунске литературе. Уз представљање могућности даљег осавремењивања студијског профила Грчки језик, књижевност, култура, а у циљу свеопште реформе традиционалне наставе, која и даље представља стуб српског високошколског образовног система, испитаћемо и ефикасност употребе Мудла у настави и учењу грчког језика, истражујући главна тежишта на којима овај софтвер почива, попут интерактивности, мултимедијалности и флексибилности садржаја.

Кључне речи: хибридно учење, онлајн учење, Moodle, грчки језик, е-платформе, интерактивност, мултимедијалност.

\section{USE OF THE ONLINE PLATFORM MOODLE IN THE REFORMED TEACHING WITHIN THE DEPARTMENT OF NEOHELENISTIC STUDIES AT THE FACULTY OF PHILOLOGY, UNIVERSITY OF BELGRADE}

\begin{abstract}
This paper examines Modern Greek language learning via the Moodle electronic platform within the "hybrid" and online learning, with the focus on the analysis of the aforementioned interactive online system in response to the demands of contemporary academic community, along with its implementation in teaching at the undergraduate level of the Department of Neohelenistic Studies at the Faculty of Philology, University of Belgrade, on the subjects such as Contemporary Greek Language 1 and Greek Literature 1. We will justify the transformation of electronic materials from initially complementary means of learning to compulsory supplementary literature. Striving for further modernization of the study profile Greek language, literature and culture, as well as for moving towards a comprehensive reform of the traditional teaching that still remains the
\end{abstract}


pillar of the Serbian higher education system, we will also examine the efficiency of using Moodle in teaching and learning the Modern Greek language, exploring the main points on which this software rests, such as interactivity, multimediality and content flexibility.

Keywords: hybrid learning, online learning, Moodle, Greek language, e-platforms, interactivity, multimediality.

\section{1. УВОД}

Историјски посматрано, проналажење оптималне дидактичке методе већ неколико векова подстиче на размишљање многе људе од науке. Забележен је податак вредан нарочите пажње у вези са општим реструктурирањем наставе. Штавише, наведено је да ce већ у доба просветитељства чешки лингвиста Јан Амос Коменски залагао за увођење слика, скица и визуелних објеката у процес учења зарад ефикаснијег усвајања знања. Као вид отелотворења његових крајње напредних

замисли средином XVII века, настао је и илустративни приручник за учење латинског језика намењен германофонима, под називом Orbis sensualium pictus, из 1658. године (Илић Марковић 2011: 365; Стојичић 2016: 25).

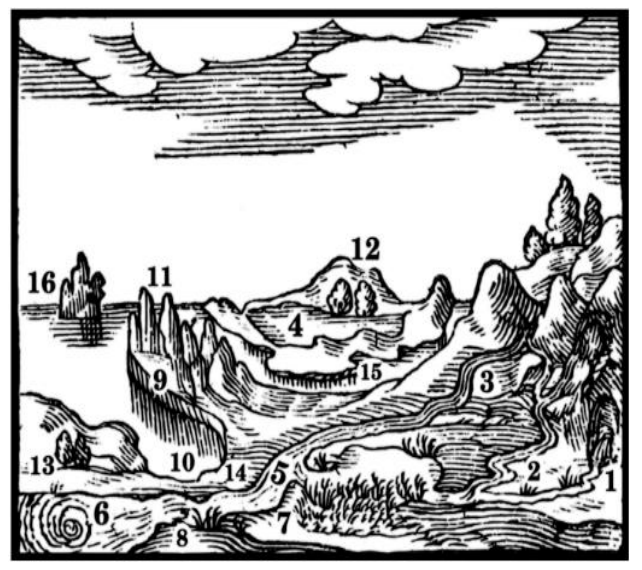

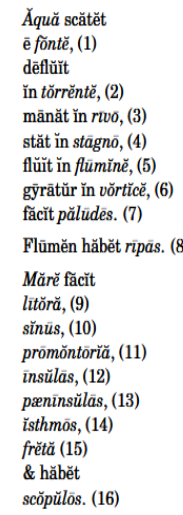

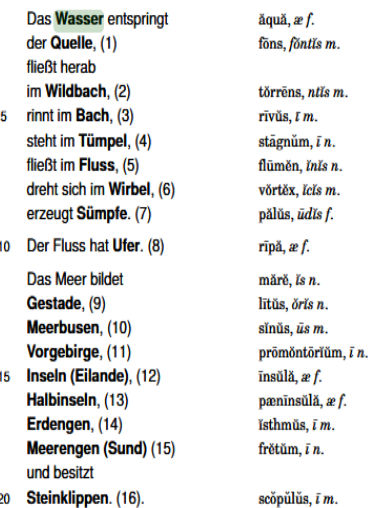

Како се може видети на слици бр. 1 и $2^{1}$, преводи латинских речи на немачки језик обогаћени су и пратећим цртежима, обележеним бројевима који им одговарају у тексту. На тај начин, реч $\breve{q u a ̆ ~ и ~ њ е н ~ е к в и в а л е н т ~ d a s ~ w a s s e r ~}$ бивају допуњене и визуелним представљањем тока воде, а по том принципу функционише и денотација осталих нових речи у тексту.

${ }^{1}$ Преузето из Comenii 1658: 16. 
Запазићемо да је овај подухват изведен два века након Гутенберговог револуционарног изума штампарије, захваљујући којем су књижне информације и знање постали доступни ширем кругу људи ренесансног периода. Сликовито речено, чешки просвећени хуманиста и педагог је на том темељу извршио културно-образовну надградњу, употребивши Гутенбергово технолошко чудо у сврхе штампања и дистрибуције двомедијалног текстуално-сликовног дидактичког материјала. Из тог разлога, није погрешно рећи да Коменијусово и Гутенбергово остварење суштински почивају на истој основи, која има за циљ уздизање људске мисли и процват науке, две упоришне тачке наступајуће просветитељске епохе. Исто тако, Коменијусов допринос науци у склопу просветне реформе добија додатно на тежини будући да је био један од првих састављача оваквих илустрованих приручника (Loucky 2008: 150), чиме оправдава епитет „родоначелника модерног учења страних језика" (Leek 2011).

Неколико векова касније, постаје још јасније да константни технолошки развитак савременог доба врши огроман утицај на све аспекте људске делатности, укључујући и образовање. Интернет, као производ информатичке револуције крајем шездесетих година прошлог века ${ }^{2}$ пружа небројене могућности за усавршавање постојећег начина наставе и учења. Из тог разлога, створени су нови образовни концепти, попут хибридног и онлајн учења на даљину, који се заснивају на дидактизацији садржаја у настави путем модерних информационо-комуникативних технологија (ИКТ), чијом имплементацијом се отвара ново поглавље у сфери образовања.

Коренитост промена биће опсежно сагледана у наредним поглављима, како бисмо уочили на који начин је, између осталог, идеја одсуства линеарности уткана у новонастале видове учења. Укратко, Бајчетић и Лазаревић у својој студији о новој врсти едукације с правом указују на важну чињеницу да таква структура онлајн курсева више није ограничена устаљеним следом наставних активности карактеристичних за традиционални вид наставе. На пример, процеси тестирања и оцењивања више нису резервисани искључиво за термине колоквијума или испита, већ се реализују у току целокупног курса. Упоредо са тим, нова образовна политика захтева активније учешће полазника курса, као и модераторску улогу наставника, чији је главни задатак „успостављање само иницијалних услова за образовни процес" (Bajčetić \& Lazarević 2007: 220).

\footnotetext{
2 Према Скјатарели (Schiattarella 2006: 1), претечом Интернета сматра се ARPANET, односно Мрежа Агениије за напредне истраживачке пројекте (Advanced Research Projects Agency Network), служећи првобитно комутацији пакета података.
} 


\section{2. ХИБРИДНО УЧЕЬЕ}

\section{1. Дефиниција и опште одлике}

Једна од образовних иновација модерног доба позната је у светској литератури под бројним синонимним називима: blended, hybrid learning (Martyn 2003), technology-mediated interactive learning (Dede 1990; Oliver \& Herrington 2003), web-enhanced и mixed-mode instruction (Kandies \& Stern 1999; Huang, Lin \& Huang 2012). Неки од српских еквивалената овим терминима били би хибридно и мешано учење (Silaški \& Marković 2011; Anđelković Labrović 2014), интерактивно учење посредовано технологијом (Kovačević 2013: 70) или настава мешовитим режимом (Howell, Harris, Wilkinson, Zuluaga, \& Voutier 2004), који заправо подразумевају комбинацију најефикаснијих елемената традиционалне фронталне (директне) наставе и разних метода предочавања дидактичког садржаја коришћењем савремених рачунарских технологија, у циљу побољшања целокупног образовног процеса (Mabed, Koehler 2012: 5004).

С тим у вези, Силашки и Марковић у својој дефиницији хибридног учења истичу да оно представља „спој класичног, традиционалног учења у физичком окружењу учионице, с једне, и учења на даљину, тј. обављања задатака који подразумевају поједине видове учења на даљину, с друге стране" (Silaški \& Marković 2011: 459). Ауторке такође наводе да у данашње време мешовито учење није ограничено папиром, уџбеником или садржајем исписаним на табли, већ се измешта и ван универзитетског седишта и захтева употребу електронских материјала, уз предуслов да постоји одржива интернет веза за приступ веб-страницама или интегративним платформама.

\section{2. Мултимедијалност као потпора традищионалном учењу}

Дакле, хибридна настава остварује се и дидактизацијом е-садржаја доступних на интернет мрежи, чиме се значајно проширује њихов дијапазон у образовне сврхе. Услед огромног обима потенцијалног материјала, веома је важно скренути пажњу на професорову улогу у академским студијама појединца. Сходно мишљењу Солдатића, наставник има задатак „да научи студента да адекватно вреднује информацију" (Soldatić 2012: 30), односно њене изворе, пружајући драгоцен допринос квалитетнијем раду правилним усмеравањем и вођењем полазника курсева кроз богату и информативну палету интернет садржаја.

Временом постаје све очигледније да уобичајени начин предавања у виду монолога, познатији као ex cathedra, face-to-face, brick-a-mortar или chalk-and-talk метод (Horvat, Alajbeg, Predanić 2015: 1041) у току којег су учесници у настави физички присутни и придржавају се приручника у физичком издању или садржаја пренетог на таблу, испољава извесне 
недостатке у односу на савремени методички приступ којим се студенти упућују и на мултимедијалне изворе.

Будући да такви наставни материјали своје уобличење проналазе у различитим форматима (текст, слика, звук, видео), овим поступком омогућава се приступ широј палети дидактичког материјала независно од времена и места. Истовремено, професорима и студентима се пружа већа слобода у раду, што резултира њиховом већом мотивисаношћу и ефикаснијем преносу и усвајању знања ${ }^{3}$.

Са једне стране, предавач, као координатор курса, може на разне начине представити предметни садржај, без ограничавања на папирни уџбенички материјал који је лишен јединственог аудио-визуелног доживљаја. Штавише, дидактизација мултимедијалног материјала постала је нужност ради бољег усклађивања са светом који је преплављен разним средствима јавног информисања или омнимедијима (Chudak 2013: 47). Подстиче се, такође, и унапређивање рада наставног особља које треба да прати и актуелну друштвено-политичку и културну ситуацију у земљи изучаваног језика, уз помоћ разних дигиталних извора. Професори су, дакле, дужни да одржавају корак са савременим токовима информатичких технологија, како би на што конкретнији и сликовитији начин представили богат језички материјал широком академском кругу, тј. студентима.

Затим, опште је познато да природни језици, као основна средства људске комуникације, непрестано еволуирају. Самим тим, постаје јасно да методе за учење страних језика, сведене на ограничен број страна, a priori нису у могућности да забележе све лингвистичке промене. Што се тиче глосара у виду самосталног издања или допуне уџбеницима за почетни ниво, у њима ће бити забележене денотације појединачних лема без уметања актуелних колоквијалнијих значења, због застарелости самих публикација које нису доживеле модерни лексички развој, али и услед своје превасходне намене, нпр. студентовог стицања основног вокабулара циљног језика. 4

3 Ова тврдња је одржива под условом да мултимедијални садржаји на најјаснији могући начин осликавају одређену појаву, о чему ће бити више речи у одељку 4.2.

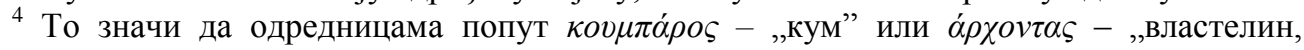
племић, великаш" (Балаћ \& Стојановић 2009: 395; 121) нису придодате и измењене савремене конотације, веома честе у данашњем новогрчком језику. Са нестанком великаша, велможа и осталих припадника феудалног периода, реч $́ \rho \chi o v \tau \alpha \varsigma$ у XXI веку јесте један пример анахронизма, на који треба обратити пажњу приликом

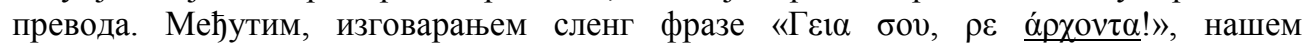
саговорнику придајемо похвално значење, оличено хиперболом попут „Где си, царе/краљу!”. Са друге стране, у реченици «Тı

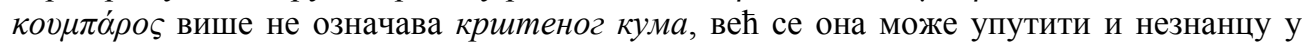
виду пријатељског обраћања, као када бисмо на српском рекли „Колико је сати, пријатељу?”. 
Наравно, ових примера има много, а због своје специфичне социјалнолингвистичке природе, тј. стварања измењених значења која се остварују у конкретним друштвеним ситуацијама, наведене фразе заслужују да буду обрађиване на настави Савременог грчког језика $Г-1$, чији је циљ стицање процедуралних знања полазника. Како је наведено у силабусу овог предмета на сајту Катедре за неохеленске студије (<http://neohelenistika.com/pdf/ savremenigrckijezikg1.pdf>), та знања се манифестују и у виду употребе практичних израза стандардног новогрчког језика у свакодневним животним аспектима (породица, образовање, посао и др.). Уз овладавање основним граматичким структурама, рецептивним, продуктивним и преводилачким вештинама на језичком нивоу А1 у складу са нормама Заједничког европског оквира за језике, учестале фразе, попут $M \varepsilon \tau \imath$ a $\chi о \lambda \varepsilon i \sigma \tau \varepsilon$ („Чиме се бавите?”), такође представљају нужан предуслов за активно служење савременим грчким језиком, што чини основне циљеве и исход овог курса.

Међутим, треба скренути пажњу и на изразе, чији буквални превод појединачних лексема не денотира семантичко значење читаве синтаксичке конструкције. Из тог разлога, полисемични устаљени израз $T l \kappa \alpha ́ v \varepsilon \tau \varepsilon$ може се разумети недвосмислено једино на основу контекста, у зависности од којег може бити преведена реченицама: „Шта радите?” или „Како сте?”. Према томе, смештањем речи и реченица у ново језичко окружење, проширује се њихов лексичко-семантички опсег, што ствара потребу и за њиховим благовременим лоцирањем употребом различитих дигиталних извора ради боље илустрације вербалног садржаја.

Прецизније, праћењем изворног аудио или видео конверзацијског материјала, у којима су заступљене речи у склопу неформалних фраза, студент може чути и видети на који начин се мења основно значење речи у зависности од контекста. Паралелно, стекао би и директан увид у актуелну употребу језика који верно осликава лингвистичку ситуацију одређеног говорног подручја у датом тренутку. Према Чакиру (Cakir 2006: 68), истраживања су показала да је имплементација аудио-визуелних садржаја у наставу веома популарна међу студентима због, како наводи, „природне контекстуализације језика”, која омогућавања да се „доживи аутентични језик у контролисаном окружењу".

\section{3. ОНЛАЈН УЧЕњЕ}

\section{1. Од огласа до електронских платформи}

Постоје бројни докази да се онлајн учење дуги низ година изузетно цени у западном свету. Почев од XVIII века, са објављивањем огласа Кејлеба Филипса (Caleb Phillips) за ступање у контакт са америчким студентима како би им слао лекције поштанским путем, преко сер Ајзака Питмена (Sir Isaac Pitman), родоначелника учења на даљину 1840 . године, којем су студенти 
поштом слали преписиване кратке библијске поруке, све до отварања британског Отвореног универзитета у XX веку и других повезаних радњи, увиђамо да корени електронског учења сежу далеко у прошлост (Soldatić 2016: 14).

Последњих неколико деценија, образовна револуција на модерним високошколским установама огледа се и у активном коришћењу електронских платформи за учење страних језика, које представљају сложен систем рада употребом информационо-комуникационих технологија. Стојичић (2016: 170), поред Myдла (<www.moodle.org>), спомиње још два значајна сајта, као што су: Blackboard (<www.blackboard.com>) и Oracle iLearning (<https://ilearning.oracle.com/ilearn/en/learner/jsp/login.jsp>). Они представљају плод иновативних замисли предузетника и чланова светске академске заједнице, насталих услед нужности развијања другачијег концепта образовања прилагођеног садашњем времену, у којем суверено владају интернет и информационе технологије.

Треба рећи да онлајн учење постоји кратко време, свега једну деценију (Стојичић, Мутавџић, Крајишник, \& Ломпар 2014: 214). Наравно, пошто истражујемо једно релативно младо поље примене електронских платформи у високошколском образовању, остављамо простора за њихово даље унапређивање и побољшање перформанси, имајући за крајњи циљ обогаћивање образовног искуства наставника и студената. Па ипак, све већи број светски признатих академских институција усваја овакав начин реализације наставе. Суботић и Бјелаковић наводе бројку која премашује 30.000 универзитетских јединица (Суботић и Бјелаковић, 2011: 283).

Као додатну потврду растућег степена распрострањености учења посредованог технологијом навешћемо веб-страницу америчког Универзитета Корнел смештеног у Итаки (Њујорк) <https://it.cornell.edu/online-learning>), која је у потпуности посвећена мешовитом учењу. Наиме, на сајту се исцрпно анализира и активно промовише концепт хибридног учења, уз предочавање Blackboard система за управљање курсевима у склопу електронског учења, који функционише по принципу Мудл платформе, о којој ће бити речи у даљем тексту.

Што се универзитета у Републици Србији тиче, чини се да је за свеопшту стандардизацију ове праксе неопходно да прође још доста времена. Међутим, једна од новина која свакако улива наду у светлију будућност нашег високообразовног система јесте све шира примена онлајн курсева за учење страних језика омогућених Мудл (Moodle) платформом. Из тог разлога, у наставку текста ћемо детаљније размотрити употребу овог интегративног система који почива на принципу хибридног учења (Silaški и Marković, 2011: 459), а од 2010. године је у активној употреби за потребе одређених предмета на академском нивоу у оквиру Филолошког факултета Универзитета у Београду (Стојичић, 2016: 195). 


\section{4. О МУДЛУ}

\section{1. Структура и цุиљеви софтвера}

Мудл представља оперативни систем у склопу интегративне софтверске платформе VLE (Virtual Learning Environment). Другим речима, замишљен је као јединствено виртуелно окружење, у нашем случају, за учење савременог грчког језика на Катедри за неохеленске студије Филолошког факултета Универзитета у Београду. Заправо, овај систем за управљање учењем (Learning Management System - LMS) јесте скраћеница од назива Modular Object-Oriented Dynamic Learning Environment, који указује на специфичну структуру Мудла. Дакле, електронско учење омогућено је приступом различитим модулима, односно засебним целинама намењеним за разноврсне функције. Како појашњава Солдатић (Soldatić 2016: 24), оне подразумевају опште и специјалне наставне активности, као што су тестирање путем вежби, задатака, квизова, семинарских радова, колоквијума и испита, објављивање дидактичког садржаја и административних процедура, попут евиденције присутних студената, њихових оцена са колоквијума/испита и др.

На веб-сајту Мудла (<www.moodle.org>) можемо се детаљније информисати о циљевима стварања овог софтверског пакета. Као што је наведено у одељку 2.2, мултимедијалност се намеће као изузетно значајан чинилац у обогаћивању наставе и учења уопште. У прилог овој тези сведочи и генеративна теорија мултимедијалног учења психолога Ричарда Мајера ${ }^{5}$, где је акценат на ефикаснијем стицању знања захваљујући принципу вишеструког начина представљања садржаја по којем функционише и Мудл платформа. У вези са тим, Мајер изричито наглашава да „људи боље уче из речи и слика, него само из речи" (Mayer 2001: Х), образлажући притом своја начела резултатима експеримента у вези са разумевањем принципа рада пумпе на бициклу. Наиме, након тестирања, испоставило се да је, од три експерименталне групе људи, принцип функционисања пумпе најбоље разумела она екипа којој је тај садржај и вербално и визуелно предочен, а не само речима или само анимацијом (2001: 161). Дакле, стварањем чвршћих веза међу садржајима пројектованих од стране различитих медија утиче се на трајније памћење садржаја.

5 За боље разумевање психолошког аспекта стицања знања и когнитивне обраде информација, његова књига Multimedial Learning представља драгоцену литературу. 


\section{2. Савремени грчки језик $\Gamma-1^{6}$}

Стављање језичког садржаја у одређени контекст и Мајеров принцип мултимедијалности можемо детаљније анализирати фокусирајући се на наставу Катедре за неохеленске студије Филолошког факултета Универзитета у Београду на основним академским студијама, почев од Савременог грчког језика Г-1 (СГ Г-1) за прву годину. Примера ради, јасно је да би тематика кулинарства обрађивана само методом таксативног навођења намирница и њиховог дефинисања представљала студенту потешкоће приликом њиховог усвајања и складиштења у дугорочној меморији. Зато би Мудл представљао погодну радну површину за постављање слика и видеоклипова у циљу јасније илустрације појмова и њихових дефиниција, чиме би се поспешило трајније памћење. ${ }^{7}$

Када је реч о постојећим садржајима доступним на курсу Савремени грчки језик $Г-1$ за академску 2017/18. годину, издвојићемо неколико репрезентативних примера:

6 За приступ наведеним онлајн курсевима неопходна је ауторизација од стране њихових аутора, односно професора са Катедре за неохеленске студије, стога ће називи и објашњења вежби у наставку текста бити изложени само илустративно.

7 Примера ради, поред формалне дефиниције речи $\lambda \dot{\alpha} \chi \alpha \nu o$ („купус") као у Речнику

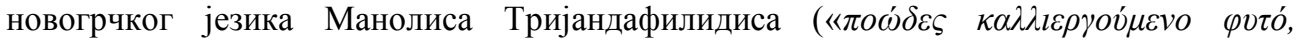

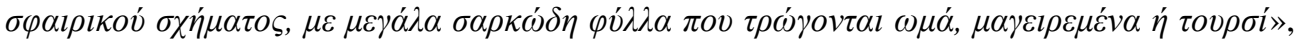
односно „зељаста узгајана биљка, округлог облика, са великим меснатим листовима који се једу сирови, кувани или у туршији”, доступне на страници < http://www.greeklanguage.gr/greekLang/modern_greek/tools/lexica/search.html?lq=\%CE\%BB\%CE\%B1\%C F\%87\%CE\%B1\%CE\%BD\%CE\%BF\&sin=all>), стајала би и одговарајућа слика купуса. На тај начин, студент би аутоматски запамтио његов изглед и имао веће шансе да, приликом наредног сусрета са истом речју, лакше призове у сећање њено значење, него уколико би само памтио дефиницију verbatim.

Са друге стране, амбициознији подухват би представљало постављање видео-клипа у коме се приказује рецепт за припрему неког јела. Студенту би се онда јасно представиле намирнице $(\lambda \alpha \dot{\alpha} \alpha \nu o)$, као и пратећа кулинарска терминологија ( $\alpha \lambda \alpha ́ \tau l$,

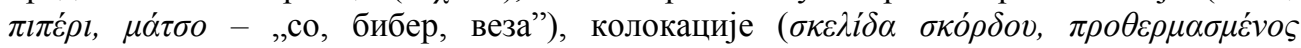

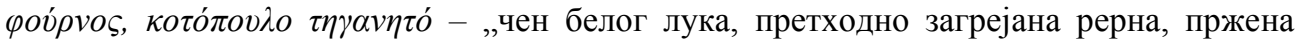
пилетина"), као и вежбе грађења глаголских облика 2. л. мн. тренутног императива аориста ( $\pi \alpha \sigma \pi \alpha \lambda i \sigma \tau \varepsilon, \alpha v \alpha \kappa \alpha \tau \dot{\psi} \psi \tau \varepsilon, \lambda \iota \omega ́ \sigma \tau \varepsilon$ - „поспите, промешајте, истопите”). Крајњи резултат оваквог стручно-апликативног приступа, где је акценат на практичним аспектима језика и његовом употребом у конкретним ситуацијама, огледао би се у могућности природног и постепеног усвајања описа читавог кулинарског процеса на грчком, као када би се вршио у изворном језичком окружењу, чиме би дошао до изражаја лингвистички феномен имерзије студента, односно „урањања” у аутентични језик. 
- Диктати; аудио-записи са транскриптом

- Презентације граматичких целина

- Речник - A1 ниво Заједничког европског оквира за језике

- Фотографије предавања и вежби са интерактивне табле

- Електронска верзија аудио-снимака дијалога из уџбеника (вежбе: Главни текст, Текст, Дијалог, Слушање)

- Питања за усмену продукцију

- Домаћи задаци у виду тестова (укључујући и ортографске вежбе)

- Лексички тест - припрема за полагање колоквијума

- Колоквијуми

- Пример завршног испита

- Пратеће илустрације

Услед велике разноврсности тематике, обима градива, али и врсте материјала постављеног на Мудлу, намеће се закључак да ови садржаји увелико излазе из оквира чисто комплементарних средстава учења. Најочигледнији докази овој тврдњи су колоквијуми и испити, као нужни елементи за успешно окончање курса, али и саме презентације и остали материјали који представљају обавезну литературу за полагање тестова. Такође, у фолдеру „Питања за усмену продукцију” садржана су сва питања

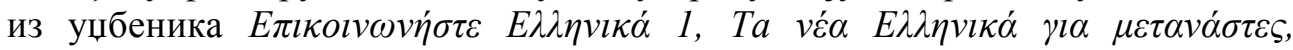

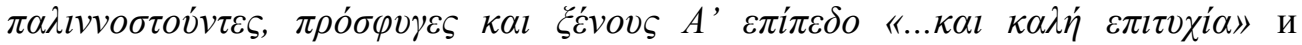
$E \lambda \lambda \eta v \iota \kappa \alpha ́$, и она представљају саставни део парцијалног дела испита из СГ $\Gamma-1$.

Након тога, посебну пажњу треба обратити на озвучене дијалоге из

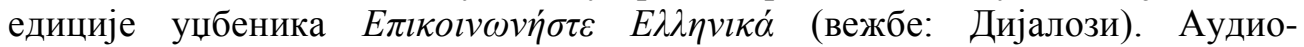
материјал је са компакт-диска пренет у Мудл виртуелну учионицу, што није забележено у ранијим генерацијама, а представља један од кључних фактора за квалитетније учење грчког језика, због студентове изложености живој речи изворног говорника, нарочито ако катедра није у могућности да обезбеди грчког лектора за извођење наставе. Уз то, студент може самостално вежбати слушање, ортографију, читање и разумевање текста код куће (Слушање, Диктат, Главни текст и др.), чиме се свакодневно активно припрема за тестове. Разноликијим садржајем се, између осталог, освежава уобичајени поступак израде домаћих задатака.

Ваља споменути да исти језички материјал предавач може искористити као основу за прављење тестова, колоквијума, испита, домаћих задатака у виду квизова или неког другог интерактивног формата. Другим речима, овом економизацијом градива предавачи би тестирали исте циљане језичке вештине, штедећи време које би иначе утрошили за претрагу новог садржаја. 
Још један значајан пројекат, који су реализовали бивши студенти неохеленистике под руководством надлежног наставника, јесте Речник са циљем обједињавања свих речи које испуњавају норму А1 нивоа знања Заједничког европског оквира за језике које је студент прве године дужан да поседује. У наставку су описани начелни принципи по којем је уређен Речник:

- Леме са преводима и ознаком рода су јасно приказане, по алфабетном редоследу: $\alpha \gamma \alpha \dot{\pi} \eta, \quad \eta$ - „љубав”, $\alpha \gamma \alpha \pi \eta \mu \varepsilon ́ v o \varsigma$,

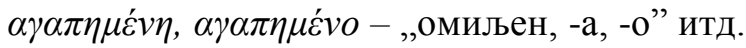

- Исказана је моција рода трородних придева и глаголских партиципа перфекта пасива, за чије су кључне речи одабрани

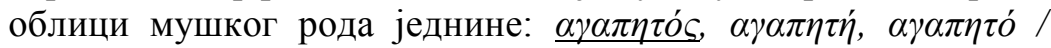

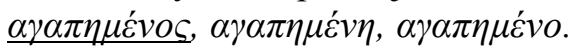

- Формиране су породице речи, деривативним лемама насталим од коренске речи: $\alpha \gamma \alpha \pi \alpha ́ \omega$ („волети”), $\alpha \gamma \alpha ́ \pi \eta$, $\alpha \gamma \alpha \pi \eta \mu \varepsilon \dot{v} o \varsigma, \alpha \gamma \alpha \pi \eta \tau o ́ s$.

Овим речником омогућена је бржа претрага најважнијих грчких одредница A1 нивоа и покривање читавог корпуса речи неопходних студентима неохеленских студија у првој години. Пошто је у питању речник за почетни ниво грчког језика, не чуди чињеница да су преводи одредница ограничени на основна значења. У Речнику су полисемичним речима, попут $\alpha \gamma \gamma \varepsilon \lambda i \alpha, \eta$, придружена значења са којима се студент прво сусреће током наставе. У овом случају, то је реч оглас, као део колокације $\mu є к \rho \varepsilon ́ \varsigma ~ \alpha \gamma \gamma \varepsilon \lambda i \varepsilon \varsigma$ („мали огласи”). Како се може видети, изостављено је и друго, књижевније значење - „вест”.

С обзиром на све до сада наведено, стиче се утисак да је овај курс конципиран на веома интерактиван начин, коришћењем мултимедијалних садржаја којима се модернизује учење грчког језика, уз њихово искоришћавање и евентуалне измене за потребе наредних генерација.

\section{3. Грчка књижевност 1}

Изучавање страног језика никада не може да се ограничи само на усвајање језика самог по себи, те је увек пожељно истражити и могућност обогаћивања градива на предметима у вези са културом и књижевношћу циљног језика, увођењем пратећих аудио- и видео-записа. Ова пракса била би од изузетног значаја за повећање интересовања студената којима ови предмети нису омиљени, а спадају у обавезне, јер би на тај начин могли да приступе усвајању дидактичког материјала из другачије перспективе.

На тај начин, уколико студент добије домаћи задатак да на Мудлу одгледа документарац који се бави био-библиографијом неког грчког писца, можемо претпоставити да ће запамтити више података о њему него други 
студент који је само учио из бележака и скрипата. Разлог томе је управо чињеница да биографски подаци из скрипата бивају трансформисани у живу реч наратора или самог протагонисте, уз истовремено праћење визуелног елемента. Стога, уколико је важно запамтити назив домовине писца Александроса Пападијамандиса, будући да се радња његових приповетки одвија управо на том месту, студент ће гледањем документарца посвећеном њему моћи да се ментално измести на острво Скијатос, што ће умногоме утицати на „урезивање” тог податка у памћење.

Навешћемо још једну методу којом се градиво може приближити студенту - то је спајање што разноврснијих формата материјала који се баве одређеном темом. Наиме, било би погрешно ограничавати се само на документарне филмове као пратеће наставно средство академскоопштеобразовних и научно-стручних предмета, као што су Грчка књижевност 1-8, односно Балканологија 1-4, Увод у неохеленистику и сл. Као репрезентативан пример једне хибридне представе академског садржаја из Грчке књижевности навешћемо капитално дело грчког песника Одисеаса Елитиса Á̆ıov $\varepsilon \sigma \tau i$, за које је музичку пратњу саставио легендарни композитор и диригент Микис Теодоракис. ${ }^{8}$ Овога пута, акценат би био на комбиновању вербалног и музичког елемента. Приказом једног од Теодоракисових бројних концерата, студент неохеленистике имао би јединствену прилику да кроз музику учи називе песама и поглавља која им припадају, истовремено усвајајући вокабулар, језичке конструкције и фразе. Коначно, дело Вредно јесте, будући да је давно превазишло уско књижевне оквире и Елитису обезбедило статус једног од највећих грчких писаца, може да се посматра и као један део мозаика грчке културе, коју полазник курса на Мудлу има могућност да искуси.

Тренутни списак материјала Грчке књижевности 1, доступног на Мудлу, састоји се од дигитализоване обавезне и допунске литературе у пдф формату, чиме се студент ослобађа обавезе одласка у библиотеку и копирницу ради прибављања литературе, штедећи тако и време и папир. Подједнако велику пажњу завређују презентације са предавања, које би могле да се окарактеришу као епитом модерног интерактивног и мултимедијалног садржаја. Пре свега, запажен је унос скенираних страница одабране литературе, које допуњују текстуални материјал презентације. Затим, дизајн презентација се доста разликује од уобичајених шаблона из програма ппт (PowerPoint), уз коришћење јарких боја и упадљивих фонтова који привлаче пажњу читаоца. Циљеви ових презентација јесу језгровито изношење научних чињеница позивањем на стручну литературу, али и стварање паралела са урбаном културом.

8 Више о Теодоракисовој музичкој обради делаิ великих грчких песника, као и о њиховом коришћењу у настави језика в. Radulović 2007. 
Као образложење претходне тврдње навешћемо део презентације који се тиче класификације ,високе” (канонске) и „ниже” (популарне) књижевности и довођењем последње у исту раван са модерним серијама доступним на сајту Нетфликс (Netflix). Сврха оваквог приступа је оправдана, имајући у виду велики број студената новије генерације којима је ова интернет услуга блиска. То значи да би студенти са већим интересовањем изучавали поменуту књижевну област. Из овога се недвосмислено извлачи закључак да повезивање научне тематике са актуелним феноменима светске популарне културе у великој мери утиче на грађење својеврсног „моста” у комуникацији између професора и студената, чинећи је непосреднијом, уз побољшање њиховог искуства у бављењу научно-стручним предметима као што је Грчка кюижевност.

\section{4. Флексибилност}

На основу претходних запажања, закључак је да се компјутерским креирањем курсева, уређивањем и архивирањем свих неопходних података о њима, као и о профилима њихових корисника, доприноси свеобухватном обједињавању обавезних и допунских чинилаца регуларног тока академских студија, чиме се ствара перманентна, а са друге стране, флексибилна база података. Укратко, сви материјали остају похрањени у систему (за разлику од папирног формата, који је подложан оштећивању), али уз могућност благовременог ажурирања или преправке.

На овом месту вреди истаћи и парадоксалан феномен објективне уштеде времена, упркос великом броју сати неопходних за уређивање материјала електронских платформи на самом почетку. Овај циљ се постиже постепеним смањењем утрошка времена и енергије услед понављања градива и задатака за сваки следећи семестар. Из овога произлази да је наставник у могућности и да прерађује постојеће градиво свуда и у сваком тренутку, стога брз и лак приступ чине Мудл веома популарним софтвером међу корисницима запосленим на катедрама факултета широм света. Платформа се одликује и изузетном материјалном флексибилношћу будући да не постоји ограничење постављаног садржаја, чиме се у огромној мери редукује количина потрошеног папира неопходног за штампање скрипата, што има за далекосежну последицу подизање еколошке свести студената.

У наставку ћемо истаћи флексибилност самих наставних материјала. Како наводи Илић Марковић (2011: 369), еволутивним следом догађаја од штампарије до интернета, унете су позитивне промене у модерни образовни систем. Промене се, услед садашњих могућности „просторног и временског прилагођавања садржаја" уносе дигиталним путем. Другим речима, нови медији савремених онлајн технологија, попут Мудл виртуелних учионица, дозвољавају једноставну корекцију, измену или надоградњу наставног материјала увек и било где, резултирајући ширењем знања прилагодљивих 
садашњем тренутку. Последично, избегавају се и преводилачки анахронизми садржаја интегрисаних у физичка издања приручника за учење страних језика, илустровани примером $\alpha ́ \chi о \nu \tau \alpha \varsigma$ у одељку 2.2.

Са друге стране, студентима је допуштено да посећују странице увек и на сваком месту, што је нарочито захвалан фактор када се има у виду велики број студената који похађа извесни курс. Такође, „свеприсутношћу” наставног материјала (Илић Марковић 2011: 365) постиже се стапање времена предвиђеног за стандардно похађање традиционалне наставе са временом намењеним индивидуализованом учењу „у приватном окружењу” (Крајишник \& Ломпар 2015: 74).

Када је, пак, реч о настави енглеског језика на београдском Економском факултету, коју похађа много студената, Силашки и Марковићева сматрају да се традиционалном комуникацијом „очи у очи” не постижу жељени резултати управо због немогућности професора да се посвете сваком студенту понаособ за разрешавање појединачних недоумица. Предавачи због рада са великим бројем студената не могу константно бити у току са њиховим тренутним нивоом знања (Silaški \& Marković 2011: 457). Наведена констатација, разуме се, у потпуности важи и за наставу других страних језика.

Пошто универзитетске јединице примају огроман број студената са разних географских подручја (како државних тако и ван граница земље која представља седиште факултета), наметнула се потреба за стварањем виртуелног окружења којим би се пренебрегнула временска и просторна удаљеност. Исход овакве праксе огледа се у равноправном статусу домаћих и иностраних студената, јер су им на располагању исти обим и формат градива неопходан за учење, израду задатака и усвајање знања. На овом месту треба истаћи став у вези са виртуелизацијом учионице путем Мудла (Radončić 2012: 180), из којег сазнајемо да навигација е-платформом, уз евентуално коришћење висококвалитетне тродимензионалне графике, позитивно доприноси стварању илузије студентовог присуства настави у стварном времену, иако физички не дели простор са осталим колегама. Напреднији интерфејс подразумева и бољи графички дизајн софтвера, којим се студент подстиче на активно учешће у настави и побољшава квалитет његовог свеукупног рада.

Поред тога, Крајишник и Ломпар сматрају да неспутаност факторима тачно утврђеног времена и простора, као важна одлика учења на даљину, значајно повећава мотивацију, односно интересовање студената. У ствари, студенти бивају растерећени због радикално смањеног утрошка времена потребног за долажење на предавања и прибављање литературе у библиотекама, књижарама или специјалистичким институтима (Крајишник \& Ломпар 2015: 74), али и због слободног одабира времена за учење и електронско праћење наставе, за разлику од фиксног термина часова у оквиру факултетске установе. Сходно томе, студент има велике користи од 
електронског учења, јер располаже својим временом на најпродуктивнији могући начин - смањено време похађања класичне наставе и проналажења извора обрнуто је пропорционално повећаном времену за саิмо учење путем платформи увек и на било ком месту, без већих дистракција.

\section{5. Интерактивност на даљину}

У одељку 2.2. упознали смо се са мултимедијалношћу, једном од главних окосница Мудла, која стоји у тесној вези са интерактивним приступом платформе. Иако није на први поглед видљива, интеракција између самог професора и студента свакако постоји. Наставник јавно дели садржај са полазницима курса, иницирајући међусобну виртуелну комуникацију. Затим, додатне интерактивне компоненте оличене су и у виду форума и причаоница. C једне стране, упућивање коментара, питања и других запажања студената могуће је вршити у форумском окружењу, укључујући тако све полазнике курса и самог предавача у конверзацију, док су причаонице, односно чет сесије (Chat sessions) намењене комуникацији у реалном времену.

Иако постоје разнородне сумње по питању делотворности виртуелне комуникације учења на даљину, попут опасности од отуђења (Rovai, Wighting 2005: 8), не треба занемарити чињеницу да степен интерактивности у неким случајевима може бити подједнако, ако не и израженији путем Мудла него приликом извођења традиционалне наставе, где се, и поред физичког присуства студента, често запажа његова психичка одсутност и суштинска незаинтересованост за одређени предмет (Стојичић 2016: 173). Ова појава често је праћена студентовом инхибираношћу, која може настати услед непознавања професора или недовољне прилагођености академском окружењу, али и као последица студентове стидљивости, анксиозности или неког другог афективног фактора.

Дакле, са психолошке тачке гледишта, дубљом анализом ове појаве поново се дотичемо фактора мотивације, без које се, како је познато, не може остварити продуктивно и угодно учење. Развијање што разноврснијих и динамичнијих курсева, тј. обрада наставног градива на нов и јединствен начин, преусмеравањем на конкретне онлајн текстуалне или аудио-визуелне садржаје, уз могућност ступања у контакт независно од времена и места, у великој мери мотивишу студента на конструктиван рад.

Ова метода преношења и усвајања знања може се упоредити са савременим дидактичким приступом директне (фронталне) наставе која се, посматрано на глобалном нивоу, још увек није у пуној мери стандардизовала, а подразумева професорово служење наставним материјалом, не само у виду језичких приручника предвиђених за одређени час, већ и мултимедијалних садржаја. Штавише, такав курс укључује и аудио-визуелне елементе, попут репродукција музике, филмова, серија, 
документарних емисија и сл. Уколико то традиционална настава не допушта због техничких немогућности и временског ограничења, Мудл испуњава улогу одличног комплементарног средства у учењу, пошто студент може у слободно време да му се посвети. Стечено знање на предавањима треба да буде применљиво у стварном језичком окружењу, захваљујући модерној фронталној настави, или активном коришћењу електронске платформе и дидактизованим интернет садржајима.

Према томе, електронске платформе служе као одлична подлога за пласирање бираних садржаја у склопу мешовитог режима рада, промовишући учење као такво, а не само подучавање (Илић Марковић 2011: 378). Услед разнородности извора којима је изложен полазник овакве врсте курсева, негује се његова способност самосталног истраживачког рада, једна од кључних вештина не само у домену академског деловања, већ и као темељ доживотног учења. На крају, константно учење, усавршавање и стицање што већег обима знања представљају императив данашњице захваљујући напредним рачунарским технологијама, које у великој мери реализују човекове просветитељске замисли у данашњем свету.

\section{5. МУДЛ - ИСКУСТВА НЕОХЕЛЕНИСТА}

Ради добијања објективнијих резултата у вези са ефикасношћу имплементације Мудл платформе у настави Савременог грчког језика, припремили смо упитник ${ }^{9}$ намењен студентима прве године Катедре за неохеленске студије Филолошког факултета Универзитета у Београду.

Упитник је за сада попунило петнаесторо студента прве године, при чему треба имати у виду да се од ове године први пут примењује реформисано креирање наставног садржаја на Мудлу. Стога се у будућности очекују репрезентативнији резултати.

Неки од најрелевантнијих резултата су следећи:

- $86 \%$ студената сматра да је градиво представљено на концизан начин;

- За четрнаесторо студената преводи и пратеће илустрације на предмету Савремени грчки језик доприносе бржем меморисању непознатих речи;

- 73\% испитаника је имало довољно времена на располагању за израду колоквијума и испита путем Мудла, наводећи као главну предност платформе аутоматско генерисање резултата (80\%)

\footnotetext{
${ }^{9}$ Питања и резултати упитника су доступни на адреси <https://docs.google.com/forms/d/1fUh_xjD3VbL0WhRJ7KmNvIzLfhnNLxVCTYaMG_L ZGYM/edit\#responses>.
} 
- Исто толико студената повремено користи Речник - A1 ниво Заједничког европског оквира за језике;

- Велика је разлика међу онима који би подржали евентуално писање састава и диктата на тастатури у будућности, а 73,3\% би прихватило организацију онлајн консултација;

- Дванаесторо студената је задовољно методичком разноврсношћу;

- Једанаесторо студената подржава хибридно учење кроз комбинацију Мудла и класичне наставе;

- Брзина и разговетност говорника у слушним вежбама не представљају проблем већини студената $(73,3 \%$ и $66,7 \%$ за оба захтева)

Ako izostanem sa predavanja, mogu bez problema samostalno da učim iz materijala sa Mudla, jer su lekcije jasno i detaljno objašnjene.

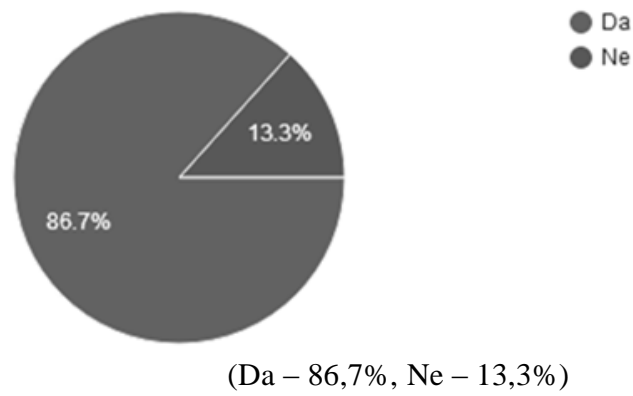

Слика бр. 3: Самостално учење путем Мудла

\section{6. ЗАКЉУЧАК}

У овом раду приказана је употреба електронске платформе Мудл (Moodle) кроз визуру хибридног и онлајн учења грчког језика на предметима Савремени грчки језик Г-1 и Грчка књижевност 1 на Филолошком факултету Универзитета у Београду, са историјским освртом на прве трагове хибридног учења. Досадашња пракса показује да је имплементација Мудла као подршка класичној настави углавном наишла на позитиван одговор студената овог факултета. Поред уштеде времена и простора за извођење курсева, односно редукције трошкова штампања скрипата, може се рећи да Мудл значајно доприноси, између осталог, и индивидуализацији процеса учења, сврсисходној употреби графичких садржаја, али и спремности студената за евентуалну свеобухватну дигитализацију курса. Крајњи циљ овог система за управљање учењем представља модеран концепт образовања, тзв. доживотно учење кроз разноврсне дидактичке материјале и 
константно усавршавање ван оквира традиционалне наставе. Најзад, остављено је простора за додатна побољшања и прилагођавање интерактивног садржаја свакој наредној генерацији, у циљу унапређивања наставе, чиме се у великој мери доприноси побољшању дидактичкометодичког приступа наставника као креатора онлајн курсева, односно оптимизацији тока академских студија крајњих корисника образовних садржаја - студената.

\section{ЛИТЕРАТУРА}

Anđelković Labrović, J. (2014). Uticaj neformalnog elektronskog učenja na razvoj ljudskih resursa (Doktorska disertacija). Univerzitet u Beogradu, Fakultet organizacionih nauka, Beograd.

Bajčetić, M., \& Lazarević, B. (2007). "Online edukacija - nove nastavničke veštine", u Savremene tendencije u nastavi jezika i književnosti, ur. J. Vučo (Beograd: Filološki fakultet): 218-223.

Балаћ, А., \& Стојановић, М. (2009). Грчко-српски речник. Београд: Завод за уџбенике и наставна средства. [Balać, A., \& Stojanović, M. (2009). Grčko-srpski rečnik. Beograd: Zavod za udžbenike i nastavna sredstva]

Dede, C. J. (1990). "The evolution of distance learning: Technology-mediated interactive learning". Journal of research on Computing in Education, 22(3): 247-264.

Илић Марковић, Г. (2011). "Употреба савремених технологија у настави страног језика. Електронска платформа „Нема проблема””, у Српски као страни језик у теорији и пракси II, ур. В. Крајишник (Београд: Филолошки факултет): 365-380 [Ilić Marković, G. (2011). "Upotreba savremenih tehnologija $\mathrm{u}$ nastavi stranog jezika. Elektronska platforma „Nema problema"”, u Srpski kao strani jezik u teoriji i praksi II, ur. V. Krajišnik (Beograd: Filološki fakultet): 365-380]

Kandies, J., \& Stern, M. B. (1999). "Weaving the Web into the Classroom: An Evolution of Web Enhanced Instruction". Pristupljeno 11.4.2018. URL: $\langle$ https://files.eric.ed.gov/fulltext/ED432270.pdf>.

Kovačević, I. Z. (2013). Efikasnost $i$ efektivnost, kognitivni stil i emocionalne reakcije korisnika $s$ obzirom na model podataka koji stoji u osnovi kompjuterskog interfejsa (Doktorska disertacija). Univerzitet u Beogradu, Filozofski fakultet, Beograd.

Comenii, J. A. (1658). Orbis sensualium pictus. Frankfurt: Friedrich Verlagsmedien.

Крајишник, В., \& Ломпар, В. (2015). ”Искуства у онлајн курсу српског као страног језика за ниво А1", у Научни састанак слависта у Вукове дане, 44/3, ур. Б. Ћорић (Београд: Чигоја штампа): 75-84 [Krajišnik, V., \& Lompar, V. (2015). "Iskustvau onlajn kursu srpskog kao stranog jezika 
za nivo A1", u Naučni sastanak slavista u Vukove dane, 44/3, ur. B. Ćorić (Beograd: Čigoja štampa): 75-84]

Loucky, J. P. (2008). "Reassessing the Educational Works and Contributions of Comenius to the Development of Modern Education". Bulletin of Seinan Jo Gakuin University 12: 149-163.

Leek, J. (2011). "John Amos Comenius - the initiator of modern language teaching and world understanding". Prace Naukowe Akademii im. Jana Dlugosza w Częstochowie. Studia Neofilologiczne 7: 224-232.

Martyn, M. (2003). "The hybrid online model: Good practice". Educause Quarterly 26(1): 18-23.

Mayer, R. E. (2001). Multimedia Learning. New York: Cambridge University Press.

Mabed, M., \& Koehler, T. (2012). "An Instructional design for developing an effective blended learning environment ", in EDULEARN12 Proceedings, ed. L. Gómez Chova, I. Candel Torres, \& A. López Martínez (Barcelona: IATED): 5003-5010.

Oliver, R., \& Herrington, J. (2003). "Exploring technology-mediated learning from a pedagogical perspective". Interactive Learning Environments 11(2): 111126.

Radončić, S. (2012). "Učenje bilo gde, na bilo kojoj lokaciji“, u Digitalizacija kulturne i naučne baštine, univerzitetski repozitorijumi i učenje na daljinu. Knj. 4: Učenje na daljinu $i$ interaktivna nastava, ur. A. Vraneš, Lj. Marković, \& G. Alexander (Beograd: Filološki fakultet): 35-51.

Radulović, I. (2007). "Za promenu nastave jezika u školi“, u Savremene tendencije u nastavi jezika i književnosti, ur. J. Vučo (Beograd: Ministarstvo za nauku i zaštitu životne sredine - Filološki fakultet): 253-259.

Rovai, A. P., \& Wighting, M. J. (2005). "Feelings of alienation and community among higher education students in a virtual classroom". The Internet and higher education, 8(2): 97-110.

Silaški, N., \& Marković, S. (2011). "Feeling in the Mood(le) for English korišćenje Mudla kao platforme za učenje engleskog jezika", u Stavovi promjena-promjena stavova, ur. J. Vučo \& B. Milatović (Nikšić: Filozofski fakultet): $457-471$.

Schiattarella, E. (2006). High-performance packet switching architectures (Doctoral dissertation). Politecnico di Torino, Scuola di Dottorato, Torino.

Soldatić, D. (2012). "Učenje na daljinu, nove metode nastave", u Digitalizacija kulturne i naučne baštine, univerzitetski repozitorijumi i učenje na daljinu. Knj. 4: Učenje na daljinu i interaktivna nastava, ur. A. Vraneš, Lj. Marković, \& G. Alexander (Beograd: Filološki fakultet): 27-32.

Soldatić, N. (2016). Teorijsko-metodološki prikaz primene Mudl platforme u nastavi stranih jezika (Masterski rad). Univerzitet u Beogradu, Filološki fakultet, Beograd. 
Стојичић, В. (2016). Рещептивне језичке активности у универзитетској настави страног језика - релаиије између модерног грчког и српског језика (Докторска дисертација). Универзитет у Београду, Филолошки факултет, Београд [Stojičić, V. (2016). Receptivne jezičke aktivnosti u univerzitetskoj nastavi stranog jezika - relacije između modernog grčkog $i$ srpskog jezika (Doktorska disertacija). Univerzitet u Beogradu, Filološki fakultet, Beograd]

Стојичић, В., Мутавџић, П., Крајишник, В., \& Ломпар, В. (2014). ”Учење на даљину - платформе за учење српског и савременог грчког као страног језика”, у Србија између Истока и Запада: наука, образовање, култура и уметност. Къ. 4: Језищи Балкана у компаративном и интердисииплинарном контексту, ур. А Вранеш \& Љ. Марковић (Београд: Филолошки факултет): 213-225 [Stojičić, V., Mutavdžić, P., Krajišnik, V., \& Lompar, V. (2014). "Učenje na daljinu - platforme za učenje srpskog i savremenog grčkog kao stranog jezika”, u Srbija između Istoka i Zapada: nauka, obrazovanje, kultura i umetnost. Knj. 4: Jezici Balkana u komparativnim i interdisciplinarnom kontekstu, ur. A. Vraneš, Lj. Marković (Beograd: Filološki fakultet); 213-225]

Суботић, Љ., \& Бјелаковић, И. (2011). "Hook up! - платформа за учење страних језика", у Српски као страни језик у теорији и пракси II, ур. В. Крајишник (Београд: Филолошки факултет): 281-287 [Subotić, Lj., \& Bjelaković, I. (2011). Hook up! - platforma za učenje stranih jezika”, u Srpski kao strani jeziku teoriji i praksi II, ur. V. Krajišnik (Beograd: Filološki fakultet): 281-287 ]

Howell, S., Harris, M. C., Wilkinson, S. A., Zuluaga, C., \& Voutier, P. (2004). "Teaching mixed-mode: a case study in remote delivery of computer science in Africa". Educational Media International 41(4): 297-306.

Horvat, T., Alajbeg, T., \& Predanić, S. (2015). "Experiences and practices in blended learning environment", in Information and Communication Technology, Electronics and Microelectronics (MIPRO), 2015 38th International Convention on Information and Communication Technology, Electronics and Microelectronics (MIPRO), ed. P. Biljanović (Opatija: IEEE): 1039-1043.

Huang, E. Y., Lin, S. W., \& Huang, T. K. (2012). "What type of learning style leads to online participation in the mixed-mode e-learning environment? A study of software usage instruction". Computers \& Education 58(1): 338-349.

Cakir, I. (2006). "The use of video as an audio-visual material in foreign language teaching classroom". TOJET: The Turkish Online Journal of Educational Technology 5(4): 67-72.

Chudak, S. (2013). "Training des Hör-Seh-Verstehens im Zeitalter der Omnimedialität des Fremdsprachenunterrichts (Überlegungen zur Qualität von Hör-Seh-Textdidaktisierungen)". Glottodidactica. An International Journal of Applied Linguistics 40(2): 47-63. 


\section{ЕЛЕКТРОНСКИ ИЗВОРИ}

Moodle. <https://moodle.org/>. (Приступљено 3. 2. 2018)

Online and Blended Learning. https://it.cornell.edu/online-learning. (приступљено 3. новембра 2018.),

Oracle iLearning. <https://ilearning.oracle.com/ilearn/en/learner/jsp/login.jsp>. (Приступљено 3. 2. 2018)

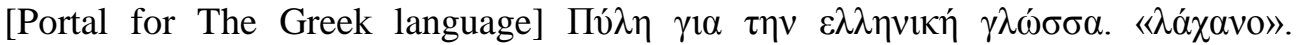
$<\mathrm{http} / / /$ www.greek-

language.gr/greekLang/modern_greek/tools/lexica/search.html?lq=\%CE\%

$\mathrm{BB} \% \mathrm{CE} \% \mathrm{~B} 1 \% \mathrm{CF} \% 87 \% \mathrm{CE} \% \mathrm{~B} 1 \% \mathrm{CE} \% \mathrm{BD} \% \mathrm{CE} \% \mathrm{BF} \& \mathrm{dq}>$.

(Приступљено 3. 2. 2018)

[Savremeni grčki jezik G-1] Савремени грчки језик Г-1. „Опште информације”. $\langle$ http://neohelenistika.com/pdf/savremenigrckijezikg1.pdf>.

(Приступљено 3. 2. 2018)

[Upitnik] Упитник: Мудл - утисци неохелениста. <https://docs.google.com/forms/d/1fUh_xjD3VbL0WhRJ7KmNvIzLfhnNL xVCTYaMG_LZGYM/edit\#responses>. (Приступљено 20.7. 2018)

Ljudmila M. Petković

University of Belgrade

Faculty of Philology

Department of Neohellenistic Studies

USE OF THE ONLINE PLATFORM MOODLE IN THE REFORMED TEACHING WITHIN THE DEPARTMENT OF NEOHELENISTIC STUDIES AT THE FACULTY OF PHILOLOGY, UNIVERSITY OF BELGRADE

\section{Summary}

This paper examines Modern Greek language learning at the university level in Serbia via the Moodle electronic platform within the "hybrid" and online learning. Firstly, we performed a brief examination concerning the evolution of established educational programmes from the plain textual material and its enrichment in the visual aspect starting from the $17^{\text {th }}$ century revolutionary concept of Jan Amos Komenský, who is deemed to have introduced images and drawings into traditional method of teaching foreign languages, and advancing to modern learning management systems. More specifically, these examples serve to demonstrate the immense progress of the higher educational system, where hybrid and online learning methods seem to have taken over primacy, pushing into the background the classical way of teaching and learning. Special attention is devoted to the analysis of the aforementioned interactive online system in response to the demands of contemporary academic community, along with its implementation in the teaching at the undergraduate level of the Department of Neohelenistic Studies at the University of Belgrade, Faculty of Philology, on subjects such as Contemporary Greek Language 1 and Greek Literature 1. Later we justified the factual transformation of electronic materials from initially 
complementary means of learning to compulsory supplementary literature. Finally, in addition to the discussion of further modernisation of the academic curriculum at the study program Language, Literature, Culture, that is, the study profile Greek language, literature, culture, and striving to reform comprehensively the traditional teaching, which continues to represent the pillar of the Serbian higher education system, we will also examine the efficiency of using the Moodle in teaching and learning the Modern Greek language, exploring the main points on which this software rests, such as interactivity, multimediality and content flexibility.

Keywords: hybrid learning, online learning, Moodle, Greek language, e-platforms, interactivity, multimediality.

Примљено: 18. 4. 2018.

Прихваћено: 15. 8. 2018. 